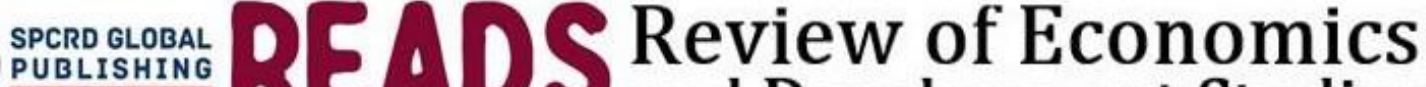 LSOS and Development Studies \\ Journal homepage: http://reads.spcrd.org \\ ISSN (Print): 2519-9692 \\ ISSN (Online): 2519-9706
}

\section{Economic Analysis of Fish Farming in Punjab, Pakistan}

\section{Muhammad Umair Aslam a, Nasir Nadeem b, Irfan Ahmed Baig c, Umer ljaz Ahmed d}

${ }^{a}$ Student of M.Sc.(Hons.) Agriculture Economics, Deptt. of Agribusiness and Applied Economics, MNS University of Agriculture, Multan, Pakistan

Email: engrmuaslam89@gmail.com

${ }^{\mathrm{b}}$ Associate professor, Department of Agribusiness and Applied Economics, MNS University of Agriculture,

Multan, Pakistan

Email: nasir.nadeem@mnsuam.edu.pk

${ }^{c}$ Professor, Department of Agribusiness and Applied Economics, MNS University of Agriculture, Multan, Pakistan Email: irfan.baig@mnsuam.edu.pk.

${ }^{\mathrm{d}}$ Assistant Professor, Deptt. of Agribusiness and Applied Economics, MNS University of Agriculture, Multan,

Pakistan

Email: umar.ijaz@mnsuam.edu.pk

\begin{tabular}{l} 
ARTICLE DETAILS \\
\hline History: \\
Accepted 18 July 2020 \\
Available Online 30 September \\
2020
\end{tabular}

Keywords:

Fish Farms, Profitability, Net Income, BCR, Food Security

JEL Classification: O10, 013

DOI: $10.47067 /$ reads.v6i3.251

\begin{abstract}
Fish consumption is veryless in Pakistan as compared to the world. The study was designed to conduct the economic analysis of the fish farming. Two districts were selected with the highest number of fish farms, i.e. Muzaffargarh and Khanewal. A total of 50 fish farms from both study areas were selected randomly for the study. Economic analysis was carried out from the collected data to estimate the profitability of fish farming. In order to make a comparison of profitability of fish farming with crop cultivation on per acre basis, data from 50 farmers from crop sector were also collected. The results revealed that fish farming was more profitable as compared to crop farming in the study area. Net income per acre was estimated at Rs. 252426 from fish farming as compared to net income per acre of Rs. 58612 from wheat-cotton, $R$ s. 72662 from cotton-rice and $R$ s. 53290 from sugarcane cultivation. The benefit cost ratio $(B C R)$ of fish farming was calculated 1:1.52 and 1: 1.74 with and without land rent respectively. It illustrates that the enterprise yields 1.52 rupees and 1.74 rupees for every rupee invested. On the basis of results, it is suggested that fish farming should be promoted, especially in the areas of saline soils to enhance food security and uplifting the socioeconomic conditions of small farmers.
\end{abstract}

(C) 2020 The authors. Published by SPCRD Global Publishing. This is an open access article under the Creative Commons Attribution-

NonCommercial 4.0

Corresponding author's email address: nasir.nadeem@mnsuam.edu.pk

\section{Introduction}

In Pakistan, the majority of the population takes maximum calories form staple food i.e. wheat 
and rice. Fifty-two percent of women having age between 15-49 years were anaemic and this percentage was higher than the world average of about 33\% (FAO, 2019). Brown (2017) stated that animal proteins are better and contain a good balance of all the amino acids that we need. Wasim (2007) also explored that fish is an outstanding source of animal protein. FAO and WHO in a study highlighted that animal protein intake should not fall below one gram per Kg body weight for adults. While, per capita availability of protein is far below the minimum daily requirement in Pakistan.

The coastline of Pakistan is approximately $990 \mathrm{~km}$ long which comprises of $270 \mathrm{~km}$ and $720 \mathrm{~km}$ of Sindh Coast and Makran Coast respectively. The Exclusive Economic Zone (EEZ) of Pakistan covers an area of about 240,000 sq. km (MFF Pakistan, 2016). The contribution of fisheries sector is vital to Pakistan's economy in terms of livelihood for the population of Pakistan especially population of coastal areas. Pakistan has a diverse sources of water comprises of sea, rivers, dams, lakes, ponds etc., where fish can be produced (GoP, 2019).

Aquaculture is being done in almost all the provinces of Pakistan. Total area of fish ponds in Pakistan is about 60.47 thousand hectares. The province wise distribution of the area is 49.17, 10.5, 0.560 and 0.240 thousand hectares in Sindh, Punjab, KPK and other provinces (Balochistan, Azad Jammun Kashmir, Northern Areas) respectively. The highest potential of aquaculture exists in the province of Sindh and Punjab. The total number of fish farms is approximately 13000 in all parts of the country. The farms are of different sizes, however, average farm size ranges between 5-10 hectares. Although no exact estimates are available about employment in the sector, however, the estimates show that about 50000 peoples are employed in the sector either directly or indirectly (FAO, 2020).

Although, the fish has been considered as an important source of protein, yet in Pakistan, due to high price and limited availability, fish consumption could not gain mass acceptance in the major urban and rural areas. However, fish trade has remained one of the promising area for fish producers as Pakistan is already exporting around 19 percent of its total production. However, more than 70 percent of the total fish production comes from the marine sites while the rest comes from inland fish farming (Haq, 2015).

Since, the last few years there has been an increasing trend of fish farming (GOP, 2015). Literature shows that fish productivity in Pakistan is low as compared to other countries of the world due to several reasons, including the socioeconomic characteristics of fish farmers, which include education, land holdings, age, ownership of capital, old technologies (Meena et al., 2002).

\section{Review of Literature}

One of the problems of agriculture sector is soil salinity in Pakistan. According to an estimate, more than 6 million hectares soils are affected by salinity in Pakistan. Moreover, more than 70 percent tube wells are pumping brackish water for irrigating soils. The problem is immense in the province of Sindh and Punjab, especially in Southern Punjab (NIAB, 2020). One of the advantages of aquaculture is that it can be adopted on the land which is not suitable for crop cultivation i.e. saline land. This problem can be turned into an opportunity by turning the area into fish cultivation without opportunity cost (Bashir et al.,2018).

Since the last few years there has been an increasing trend of fish farming (GOP, 2015). Literature shows that fish productivity in Pakistan is low as compared to other countries of the world due to several reasons including socioeconomic characteristics of fish farmers which include education, land holdings, age, ownership of capital, old technologies (Meena et al., 2002). Shah et al.(2017) 


\section{Review of Economics and Development Studies, Vol. 6 (3) 2020, 625-637}

concluded that despite of gradually increase in growth of inland fish production and exports, it is low as compared to other developing countries. The study explained that aquaculture has developed as the potential way to meet fish demand, food security, livelihood, employment and national income. Moreover, they suggested that government should develop and expand this sector as it has the potential to offer various opportunities to support livelihood in Pakistan.

Qasim et al. (2004) studied the economics of fish production and marketing in saline areas of the central Punjab by taking sample of 33 farmers randomly. They calculated that per acre fish production was $1524 \mathrm{kgs}$. Sale price was Rs. 55 per kg. Total variable cost per hectare estimated was Rs. 45513 and total revenue was Rs. 127531 for those fish farmers who made their farms at non saline soils while total variable cost and total revenue per hectare of saline soils fish farms was Rs. 45513 and Rs. 73219 respectively. Profit (Rs. 40488 per hectare) of fish farms of non saline soils was high as compared to that of saline soil (Rs 30029). Bashir et al. (2018) also estimated the profitability of fish farming in Hafizabad district and concluded that per acre cost of production was Rs. 199310.70 on large farms as compared with medium and small farms. The net earnings per acre was calculated at Rs. 59298. The benefit cost ratio was estimated 1.0:1.3, indicating earning of Rs. 1.3 on every rupee spent in the enterprises.

Fish farming plays vital role in improving the socioeconomic conditions of rural people (Mazid, 2002). Fish farming creates miscellaneous income opportunities for a number of people, especially those who live below the poverty line (Ahmed et al., 2005). Pond fish farming was proved to be more profitable as compared to rice cultivation, therefore, in the rural areas so many farmers have changed their rice field into pond fish farming (Islam et al.,2002). Olawumi et al., (2010) found fish farming as a profitable enterprise. They concluded that fish seed stocked, labour, the size of the pond and waste feed of poultry were the dominant factors of the income which increased the small holding production of fish in Nigeria. Olaoye et al. (2013) assessed the socioeconomic analysis of pond farming in Nigeria and

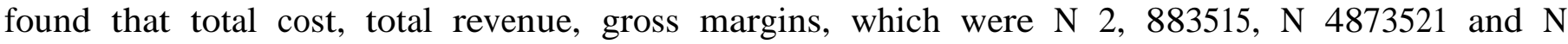
2,376,616.36 respectively. The estimated benefit cost ratio was 1: 1.69 which shows that fish farming has the potential to alleviate poverty of farmers. Okpeke and Akarue (2015) appraised the profitability by calculating total cost, total revenue and net revenue. The total cost per farming season was estimated at N976, 622 while total revenue was N976, 622. The net farm income was estimated at N 384, 306 per farmer per annum, which reflects that fish farming is a profitable enterprise. Adewuyi et al. (2010) estimated average total cost of N394,380 per annum and gross revenue of $N 715030$. The estimated profit was 320650 Nigerian Naira. The estimated rate of return was 0.55 Nigerian Naira. The results of regression analysis showed that variables pond size, labour, cost of lime, cost of feeds and fingerlings have significant impact on output. The elasticity of pond size, labor, feeds, fertilizer, lime, fixed input and fingerlings was found $0.029 \%, 0.057 \%, 0.005 \%, 0.534 \%, 0.007,0.79 \%$ and $0.001 \%$ respectively. The study suggested the fish production as profitable business activity in the study area. NamonjeKapembwa and Samboko (2020) estimated the profitability of small-scale aquaculture production in Zambia by employing primary data collected through individual interview and focus group discussion. They found that benefit-cost ratio was greater than one, implying that an investment in aquaculture was a profitable over the useful life of 10 years. They further estimated net present value(NPV), and internal rate of return and established that it was $17524 \mathrm{ZMW}$ and 42.38 percent at 15 percent discount rate respectively. The positive NPV indicated that aquaculture business was a profitable business in Zambia. Irz and Mchenzie (2003) they evaluated the profitability and technical efficiency of aquaculture in Philippines by comparing the two production systems, i.e. intensive monoculture of tilapia in freshwater ponds and an extensive poly culture of shrimps in brackish water ponds and concluded that aquaculture in both systems was very profitable. However, higher profitability was achieved in 
brackish water ponds. As for technical efficiency is concerned, it was concluded that technical efficiency was higher in freshwater aquaculture as compared to brackish water aquaculture. Olagunju et at. (2007) they estimated gross margin and profitability ratio of catfish in Ibadan metropolis, Oyo State, Nigeria and found that the average total cost per kg of fish was N 204 and average total revenue per $\mathrm{kg}$ of fish was N 308. The estimated gross margin was N 194.60 per kg of fish produced. They also found a significant relationship between total revenue and cost of feed, years of farming experience, size of pond and labor.

\section{Research Methodology}

To estimate the economics of fish farming, primary data were collected from 50 fish farms through random sampling technique from top 2 farm fish producing districts i.e. Mazaffargarh and Khanewal in Punjab. Similarly, data from 50 non fish farmers was also collected from the same vicinity to compare the profitability of fish farming. Detailed data on cost of production of fish farming and crop farming was taken through well designed questionnaire. In addition to that benefit cost ratio (BCR) was also calculated for calculating the profitability of fish farming per rupee invested.

\subsection{Economic Analysis}

\subsubsection{Budgetary Techniques}

In this technique, cost and return were estimated to estimate the economic analysis of fish farming. Following formula for estimation of cost, revenue, economic profit, business profit, gross margins and benefit cost ratio were employed and are given as:

Total revenue $(\mathrm{TR})=$ Total fish produced $*$ Average price of fish .

Gross margin $(\mathrm{GM})=\mathrm{TR}-$ Total Variable cost $(\mathrm{TVC})$ for producing fish

Economic profit $=\mathrm{TR}-[$ explicit cost + implicit cost $]$

Business profit $=\mathrm{TR}-[$ explicit cost $]$

Benefit cost ratio $(\mathrm{BCR})=$ Business profit/TVC (When imputed cost is not taken)

\subsection{Results and Discussion}

Education status of fish farmers is given in table 1. The table shows that $78 \%$ farmers have their education upto martirc and $22 \%$ fall under the range of intermediate to master level education.

\section{Table 1: Education Status of Fish Farmers}

\begin{tabular}{|c|l|l|}
\hline Schooling Years & Frequency & Percent \\
\hline $1-10$ & 39 & 78.0 \\
$12-18$ & 11 & 22.0 \\
Total & 50 & 100.0 \\
\hline
\end{tabular}

Classification of fish farmers with respect to age illustrated that $30 \%$ farmers were having age between 18 to 30 years and $44 \%$ were below the range of $31-40 \%$ and limited number of $26 \%$ were those who were above 40 years of age. It explains that the majority of the farmers are young and energetic. Studies such as (Khatun et al. 2013; Peter and Susan, 2014) also concluded that the majority of the fish farmers were young. Table 3 displays the information of experience of fish farming. It was found that $40 \%$ had experienced between 1 to 5 years while $60 \%$ were doing since last 6 to 10 years. Since this enterprise was not popular among the farmers, however the demonstration impact of profitability had attracted the other farmers especially small farmers to adopt the enterprise. 
Table 2 : Classification of Fish Farmers With Respect to Age

\begin{tabular}{|l|l|l|}
\hline Age range & Frequency & Percent \\
\hline $18-30$ & 15 & 30.0 \\
\hline $31-40$ & 22 & 44.0 \\
\hline Above 40 & 13 & 26.0 \\
\hline Total & 50 & 100.0 \\
\hline
\end{tabular}

Table 3: Experience of Fish Farming

\begin{tabular}{|c|c|c|}
\hline Years & Frequency & Percent \\
\hline $1.00-5.00$ & 20 & 40.0 \\
\hline $6.00-10.0$ & 30 & 60.0 \\
\hline Total & 50 & 100.0 \\
\hline
\end{tabular}

Table 4 demonstrates that only $4 \%$ farmers had taken loan while $96 \%$ had not taken loan for fish farming. One of the inhabiting factors was the complexity involved in the procedure of loan taking. Studies like Bashir and Azeem (2008) indicated a lot of problems for getting formal loan.

\section{Table 4: Loan Taken by Fish Farmers}

\begin{tabular}{|l|l|l|}
\hline Farmers & Frequency & Percentage \\
\hline Loan taken & 2 & 4 \\
\hline Loan not taken & 48 & 96 \\
\hline Total & 50 & 100 \\
\hline
\end{tabular}

The marketing of a product is one of the important areas of any enterprise. Table 5 displays that the majority of the farmers sold their produce to big cities (i.e. $40 \%$ ) while $30 \%$ sold at local markets and $30 \%$ took their produce both at local and big cities markets. The main reason for selling in big markets was to fetch high income from the sale of their produce. As for the distance of the market from their farm is concerned, table 6 depicted that the maximum distance of big markets was 300 to $400 \mathrm{~km}$ and the minimum distance of market ranged from 9 to $20 \mathrm{~km}$.

\section{Table 5: Sale of Fish With Respect to Market}

\begin{tabular}{|l|l|l|}
\hline Sale of Fish & Frequency & Percent \\
\hline Local & 15 & 30.0 \\
\hline Big City & 20 & 40.0 \\
\hline Both & 15 & 30.0 \\
\hline Total & 50 & 100.0 \\
\hline
\end{tabular}


Table 6: Distance From Market Where They Sell Their Produce

\begin{tabular}{|l|l|l|}
\hline Distance & Frequency & Percentage \\
\hline 9 to $20 \mathrm{~km}$ & 15 & 30 \\
\hline 35 to $100 \mathrm{~km}$ & 15 & 30 \\
\hline 300 to $400 \mathrm{~km}$ & 20 & 40 \\
\hline Total & 50 & 100 \\
\hline
\end{tabular}

Use of feed is an important ingredient for better production. The results given in table 7 show that the majority of farmers used the formulated fish feed while $24 \%$ were using self-prepared feed. Those who were found using both type of feed were $32 \%$. Formulated feed was popular among the fish farmers, however, there is still enough room to increase the production of fish feed. Moreover, the quality standards are also required to be monitored. As regards the number of fingerlings put in the fish farm of one acre size, table 8 discloses that $90 \%$ farmers put 600 to 800 fingerlings in one acre farm and only $10 \%$ release 800 to 900 fingerlings in one acre pond.

\section{Table.7: Source of Fish Feed}

\begin{tabular}{|l|l|l|}
\hline Source of Fish Feed & Frequency & Percent \\
\hline Formulated & 22 & 44.0 \\
\hline Self-Prepared & 12 & 24.0 \\
\hline Both & 16 & 32.0 \\
\hline Total & 50 & 100.0 \\
\hline
\end{tabular}

Table 8: Number of Fingerlings Per Acre

\begin{tabular}{|l|l|l|}
\hline No. of fingerlings per acre & Frequency & Percent \\
\hline $600-800$ & 45 & 90.0 \\
\hline $800-900$ & 5 & 10.0 \\
\hline Total & 50 & 100.0 \\
\hline
\end{tabular}

The ownership status of fish farms indicates that $46 \%$ fish farmers were owner, $42 \%$ were found tenants while $12 \%$ were owner cum tenants. It means that most of the farmers had their own farms (table 9). The classification of farmers discloses that $36 \%$ farmers were small, $34 \%$ were found medium while $30 \%$ were estimated to be owner cum tenants as shown in table 10 . 
Review of Economics and Development Studies, Vol. 6 (3) 2020, 625-637

Table 9: Land Ownership Status

\begin{tabular}{|l|l|l|}
\hline Ownership status & Frequency & Percentage \\
\hline Owners & 23 & 46 \\
\hline Tenants & 21 & 42 \\
\hline Owner cum Tenants & 6 & 12 \\
\hline Total & 50 & 100 \\
\hline
\end{tabular}

Table 10: Classification of Farmers Categories

\begin{tabular}{|l|l|l|}
\hline Farm type & Frequency & Percentage \\
\hline Samll Farms (1-7 acres) & 18 & 36.0 \\
\hline $\begin{array}{l}\text { Medium Farms (8-25 } \\
\text { acres) }\end{array}$ & 17 & 34.0 \\
\hline $\begin{array}{l}\text { Large Farmers (> 25 } \\
\text { acres) }\end{array}$ & 15 & 30.0 \\
\hline Total & 50 & 100 \\
\hline
\end{tabular}

Note: categories based on discussion with fisheries officer

Table 12: Types of Fish Cultured

\begin{tabular}{|l|l|}
\hline Type of fish & Frequency \\
\hline Rahu & 50 \\
\hline Thaila & 48 \\
\hline Grass Carp & 15 \\
\hline Mori & 5 \\
\hline Malli & 4 \\
\hline Singhari & 4 \\
\hline Tilapia & 1 \\
\hline Gulfam & 1 \\
\hline Silver Carp & 1 \\
\hline
\end{tabular}




\subsection{Analysis of Non Fish Farmers}

\section{Table 12: Types of Fish Cultured}

\begin{tabular}{|l|l|l|l|l|l|}
\hline & N & Minimu & Maximu & Mean & Std. \\
\hline Education & 50 & 0 & 16 & 4.90 & 5.148 \\
\hline Age & 50 & 17 & 75 & 42.60 & 16.284 \\
\hline Experience & 50 & 2 & 50 & 21.72 & 14.995 \\
\hline $\begin{array}{l}\text { Farm distance from } \\
\text { main road (Km) }\end{array}$ & 50 & 1 & 7 & 3.01 & 2.057 \\
\hline Family Size & 50 & 2 & 26 & 8.42 & 4.682 \\
\hline D_Market & 50 & 1.00 & 300.00 & 15.2600 & 41.84986 \\
\hline Valid N (listwise) & 50 & & & & \\
\hline
\end{tabular}

The experience of non-fish farmers discloses that they had experience ranges from one year to more than 40 years. 34\% farmers had experience ranging from 1 T0 10 years, followed by $30 \%$ farmers had 11 to 20 years of experience. $36 \%$ farmers were those having experience ranging from 21 to more than 40 years as presented in table 13 .

Age classification of the farmers reveals that $32 \%$ farmers were those having age between 18 to 30 years and $22 \%$ were comprised of the farmers having age between 31 to 40 years as shown in table 14. While the rest $46 \%$ have experienced more than 40 years. One thing which is clear from the comparison of age between fish farms and non-fish farmers is that fish farmers are relatively more younger as compared to non-fish farmers (farmers growing crops).

\section{Table 13: Farming Experience}

\begin{tabular}{|l|l|l|}
\hline Years & Frequency & Percentage \\
\hline $1 \_10$ & 17.0 & 34 \\
\hline $11 \_20$ & 15.0 & 30 \\
\hline $21 \_30$ & 6.0 & 12 \\
\hline $31 \_40$ & 6.0 & 12 \\
\hline$>40$ & 6.0 & 12 \\
\hline Total & 50.0 & \\
\hline
\end{tabular}


Table 14: Age Distribution of Crop Farmers

\begin{tabular}{|l|l|l|}
\hline Age & \multicolumn{1}{|c|}{ Frequency } & Percentage \\
\hline $18 \_30$ & 16 & 32 \\
\hline $31-40$ & 11 & 22 \\
\hline $41-50$ & 10 & 20 \\
\hline$>50$ & 13 & 26 \\
\hline Total & 50 & \\
\hline
\end{tabular}

The distribution of non-fish farmers with respect to education illustrates that a big proportion of farmers were illiterate (i.e. $40 \%$ ) and the second significant segment of the classification comprises of holding primary education. Twenty percent farmers were having education upto Matriculation, followed by $6 \%$ Bachelor and another 6\% got Mater degree (Table 15).

\section{Table 15: Educational Status of non-Fish Farmers}

\begin{tabular}{|l|l|l|l|}
\hline S.No. & Education & Frequency $(\mathrm{n}=50)$ & Percentage \\
\hline 1 & Illiterate & 20 & 40 \\
\hline 2 & Primary & 14 & 28 \\
\hline 3 & Matriculation & 10 & 20 \\
\hline 4 & Bachelor & 3 & 6 \\
\hline 5 & Master & 3 & 6 \\
\hline & Total: & 50 & \\
\hline
\end{tabular}

One of the main objectives of the study was to compare the profitability of fish farming and crop cultivation in the study area. Table 16 demonstrates per acre cost of production of fish farming. Average gross cost per acre was estimated at Rs. 96624 and average gross income per acre was estimated at Rs. 349050. The calculated net income per acre was Rs. 252426. The Benefit cost ratio had been estimated at 1: 3.61 which illustrates that the enterprise yields 3.61 rupees for every rupee invested. The results of our study also find support from the studies of (Bashir et al., 2018; Qasim et al., 2004).

\section{Table 16: Per Acre Cost of Production of Pond Fish}

\begin{tabular}{|l|l|l|}
\hline S.No. & Income and Cost items & Rupees. \\
\hline 1 & Average fertilizer cost/ Acre & 2656 \\
\hline 2 & Average feed cost per acre & 158760 \\
\hline 1 & Average disease cure cost per acre & 678 \\
\hline 2 & Average electricity and fuel cost per acre & 21298 \\
\hline 3 & Average labour cost per acre & 17340 \\
\hline 4 & Average cost of fingerling per acre & 449 \\
\hline 5 & Average rent of farm per acre & 27828 \\
\hline 6 & Average gross cost per acre & 229009 \\
\hline
\end{tabular}


Review of Economics and Development Studies, Vol. 6 (3) 2020, 625-637

\begin{tabular}{|l|l|l|}
7 & Average gross Income per acre & 349050 \\
\hline & Average Net income & 120041 \\
\hline & BCR & 1.52 \\
\hline
\end{tabular}

The profitability estimates of crop cultivation in the study area discloses that per acre cost of production (with land rent) for wheat, rice, cotton, s/cane and fodder cultivation was Rs. 41079, Rs. 50825, Rs. 64158, Rs. 79513 and Rs. 426465 respectively. Similarly, per acre cost of production (without land rent) for wheat, rice, cotton, s/cane and fodder cultivation was calculated at Rs. 22443, Rs. 32189, Rs. 45522, Rs.60877 and Rs.24010 respectively. The net income with land rent for the same crops was estimated at Rs.11756, 25806, 9584, 34654 and Rs. 437 respectively, while the estimates of net income without land rent was estimated at Rs.30392, 44442, 28220, 53290 and Rs. 19073 respectively, for the same crop. The estimated BCR shows that all crops have BCR above 1, however, it is highest for Rice crop followed by S/cane and wheat. The BCR for cotton crop is the lowest due to the high cost of production and effect of climatic change. Moreover, prices of cotton were not encouraging, therefore, the farmers were found reluctant to grow the crop (Table 17).

Table 17: Per Acre Cost of Production of Crops

\begin{tabular}{|l|l|l|l|l|l|}
\hline Crops & Wheat & Rice & Cotton & S/Cane & Fodder \\
\hline Land Preparation cost & 2606 & 4814 & 4833 & 7500 & 2073 \\
\hline Seed Bed Prep. Cost & 2301 & 2527 & 2000 & 3500 & 1980 \\
\hline Seed Cost & 2125 & 1503 & 3138 & 9000 & 6400 \\
\hline Fertilizer cost & 7835 & 7765 & 11168 & 7200 & 6500 \\
\hline Plant Protection cost & 1222 & 4326 & 13706 & 3667 & 2100 \\
\hline Irrigation cost & 1970 & 7462 & 6210 & 8135 & 2100 \\
\hline Harvesting cost & 3317 & 2725 & 3400 & 12500 & 2357 \\
\hline Land Rent (6 months) & 18636 & 18636 & 18636 & 18636 & 18636 \\
\hline Labor cost & 1067 & 1067 & 1067 & 1500 & 500 \\
\hline Marketing cost & 0 & 0 & 0 & 7875 & 0 \\
\hline Production cost (with land rent) & 41079 & 50825 & 64158 & 79513 & 42646 \\
\hline Production cost (without land & 22443 & 32189 & 45522 & 60877 & 24010 \\
\hline Gross income per acre & 52835 & 76631 & 73742 & 114167 & 43083 \\
\hline Net income (with land rent) & 11756 & 25806 & 9584 & 34654 & 437 \\
\hline Net income (without land rent) & 30392 & 44442 & 28220 & 53290 & 19073 \\
\hline BCR & 1.29 & 1.51 & 1.15 & 1.44 & 1.01 \\
\hline
\end{tabular}

Since fish farming takes a year to harvest, therefore, comparison of both the enterprises is required to be made on the basis of net income received annually. Table 18 explains per acre per year net income earned from crop cultivation with and without land rent. 
Net income from a wheat-cotton combination was estimated at Rs. 21340 with land rent and Rs. 58612 had been calculated without land rent. The cotton- rice combination reveals that net income obtained by the farmers was calculated at Rs. 35390 with land rent and Rs. 72662 without land rent. The net income earned by sugarcane farmers was estimated at Rs. 34654 including land rent while it was Rs. 53290 excluding land rent (Table 18). Table 19 reveals that net income from fish farming is Rs. 120041 and Rs. 147869 with land rent and without land rent respectively. The comparison of the estimates of income earned per acre from crop sector and income earned per acre from fish farming concludes that fish farming is a more profitable enterprise as compared to crop cultivation. The results of Gachucha et al. (2014) also showed that fish farming was a profitable business compared to maize crop farming in Kenya.

\section{Table 18: Per Year Per Acre Net Income from Different Combinations of Crop Cultivation}

\begin{tabular}{|l|l|l|}
\hline $\begin{array}{l}\text { Net income from crop } \\
\text { cultivation }\end{array}$ & $\begin{array}{l}\text { Per Year Net income (with } \\
\text { land rent) (Rs.) }\end{array}$ & $\begin{array}{l}\text { Per Year Net income } \\
\text { (without land rent) (Rs.) }\end{array}$ \\
\hline Wheat-Cotton & 21340 & 58612 \\
\hline Cotton-Rice & 35390 & 72662 \\
\hline S/Cane & 34654 & 53290 \\
\hline
\end{tabular}

Table 19: Per Year Per Acre Net Income from Fish Farming

\begin{tabular}{|l|l|l|}
\hline Income from fish farming & $\begin{array}{l}\text { Per Year Net income (with } \\
\text { land rent) (Rs.) }\end{array}$ & $\begin{array}{l}\text { Per Year Net income } \\
\text { (without land rent) (Rs.) }\end{array}$ \\
\hline Fish Farming & 120041 & 147869 \\
\hline
\end{tabular}

\section{Conclusions}

The study has been designed to conduct the economic analysis of the fish farming in the study area. Two districts were selected with the highest number of fish farms, i.e. Muzaffargarh and Khanewal. A total of 100 farms, (50 fish farms and 50 non fish farms) from both study areas was selected randomly for the study. Economic analysis was carried out from the collected data to estimate the profitability of fish farming. Moreover, for comparison purpose, data from 50 crop growing farmers were also collected. The results revealed that fish farming was more profitable as compared to crop farming in the study area. Net income per acre was estimated at Rs. 252426 from fish farming as compared to net income per acre of Rs. 58612 from wheat-cotton combination of crops, Rs. 72662 from cotton-rice combination of crops and Rs. 53290 from sugarcane cultivation. The benefit cost ratio (BCR) of fish farming was calculated 1:3.61 which illustrates that the enterprise yields 3.61 rupees for every rupee invested. 


\section{Recommendations}

On the basis of results, it is suggested that fish farming is a profitable business and it could help to the farmers especially small land holders to adopt the fish farming, which will not only improve their socioeconomic conditions, but also shall be helpful for combating the issue of food security at the household, community and at national level. At the same time it could earn foreign exchange for the country also. It is more suitable for those who have severe issues of salinity as crops are difficult to grow well in saline soils.

Fish farming instead of traditional agriculture has been seen as a way to increase agricultural profits from saline affected land

\section{Acknowledgement}

This study has been supported by Higher Education Commission (HEC) of Pakistan under NRPU project No. 10426. I acknowledge the support of HEC in accomplishing the work on the project.

\section{References}

Adewuyi, S.A., B.B. Phillip, I. A. Ayinde and D. Akerele.2010. Analysis of Profitability of Fish Farming in Ogun State, Nigeria. J Hum Ecol, 31(3): 179-184

Ahmed, N., M.M. Rahman and M.M. Rahman.2005. A Study on Fish Marketing System in Gazipur, Bangladesh, Pakistan J. Biol. Sci., Vol. 8, No. 2, pp. 287-292.

Bashir, A., S. Ambren, I.Mahmood and S.A. Tariq. 2018. Prospects of fish farming in saline areaq of ricewheat cropping system of the Punjab. J Agric. Res., 2018, Vol. 56(1): 57-62.

Bashir, M.K. and M.M. AzeeM.2008. Agricultural Credit in Pakistan: Constraints and Options. Pak. j. life soc. sci. 6(1): 47-49

Brown, M.J. (2017) Animal vs. Plan Protein-What is the Difference. Accessed on 15-10-2017 from https://www.healthline.com/nutrition/animal-vs-plant-protein\#section1.

FAOa. 2019. Aquaculture growth potential in Pakistan. WAPI fact sheet to facilitate evidence-based policy-making and sector management in aquaculture.

FАОв.2019. Global Fishery and Aquaculture Production Statistics v2019.1.0, published through FishStatJ. Food and Agriculture Organization of United Nation. www.fao.org/fishery/statistics/software/fishstatj/en).

FAO.2020. National Aquaculture Sector Overview. Food and Agriculture Organization, e-Bulletin.

Gachucha,M., B. Njehia and P.MsheNGA.2014. Opportunities in adoption of commercial fish farming as a new enterprise for small scale farmers in Kisii county, Kenya. 1(1):1-5

GOP. 2015. Agric. Statistics of Pakistan, Statistic Div. Islamabad.

GoP. 2019. Economic Survey of Pakistan. Ministry of Finance, Government of Pakistan.

Haq, S. (2015). Fishing for Investment and Growth in Sector. The Express Tribune. https://epaper.tribune.com.pk/main.aspx

Irz, X., V. Mckenzie. 2003. Profitability and Technical Efficiency of Aquaculture Systems in Pampaanga, Philippines. Aquac. Econ. Manag. 2003, 7, 195-211, DOI:10.1080/13657300309380340

Islam, M.S., S.M. Murshed, M. Moniruzzaman and M.A. Baree. 2002. Rice-cum Fish Farming in Selected Areas of Mymensingh District, Online J. Biol. Sci. 2(10):715-718.

Khatun, S., R K Adhikary, M Rahman, M Nurul Azim Sikder and M Belal Hossain. 2013. Socioeconomic status of pond fish farmers of Charbata, Noakhali, Bangladesh. Int. J. LifeSc. Bt \& Pharm. 2(1):356-365

Mazid, M.A. 2002. Development of fisheries in Bangladesh, Plan and Strategies for Income Generation and Poverty Alleviation. Middle-East J. of Sci. Res.,129(3): 301-306 
Meena, S.B., T.N. Kirway, N.M. Lema, N. Itolela. 2002. Farming system approach to technology development and dissemination. Guide for Training at Certificate and Diploma Levels. Color Print limited, Ministry of Agriculture and Food Security, Dares Salaam, pp. 228.

MFF Pakistan. 2016. A Handbook on Pakistan's Coastal and Marine Resources. MFF Pakistan, Pakistan. $78 \mathrm{pp}$.

Namonje-Kapembwa, T and P.Samboko. 2020. Is aquaculture production by small-scale farmers profitable in Zambia. International Journal of Fisheries and Aquaculture.12(1):6-20

NIAB.2020. Nuclear Institute for Agriculture and Biology, Faisalabad, Pakistan. Website accessed on 801-2020 http://www.niab.org.pk/soil.htm/

Okpeke, M. Y., \& B.O. Akarue. 2015. Analysis of the profitability of fish farming in Warri South Local Government Area of Delta State, Nigeria. IOSR Journal of Agriculture and Veterinary Science (IOSR-JAVS), 8(12): 45-51.

Olagunju, F. I., I.O. Adesiyan, and A. A. Ezekiel. 2007. Economic viability of cat fish production in Oyo State, Nigeria J. Human Ecology 21(2): 121 - 124.

Olaoye, O. J, S.S. Ashley-Dejo, E.O. Fakoya, N.B. Ikeweinwe, W. O.Alegbeleye, F.O. Ashaolu, and O.A. Adelaja. 2013. Assessment of Socio-Economic Analysis of Fish Farming in Oyo State, Nigeria. Global Journal of Science Frontier Research Agriculture and Veterinary Volume 13(9):1-13

Olawumi, A.T., A.O. Dipeoluand O.M. Bamiro.2010. Economic Analysis of Homestead Fish Production in Ogun State Nigeria, Journal of Human Ecology, 31(1):13-17

Peter, M., and S.Susan. 2014. Determinants of Adoption of Pond Fish Farming Innovations in Salamaua of Morobe Province in Papua New Guinea. South Pacific Studies, 35 (1):21-36

Qasim, M., A.D.Sheikh, M.Abbas and M.Kashif. 2004. Economics o fish production and marketing in saline areas of the central Punjab. Pak. J Agri. sci., Vol. 41(3-4):91-94

Wang F, Zhang J, Mu W, Fu Z, Zhang X .2009. Consumers" perception toward quality and safety of fishery products, Beijing, China. Food Control 20: 918-922.

Wasim, M.P. 2007. Issues, Growth and Instability of Inland Fish Production in Sindh (Pakistan) Spatial - Temporal Analysis. Pakistan Economic and Social Review. 45(2); 203-230. 